\title{
Altered expression of leptin and leptin receptor in the development of immune-mediated aplastic anemia in mice
}

\author{
XIANGCONG YIN $^{1}$, JIE YANG $^{1}$, YUHUA LIU ${ }^{2}$, JIAN ZHANG $^{3}$, CHUNLEI XIN ${ }^{4}$, HONGGUO ZHAO $^{5}$,

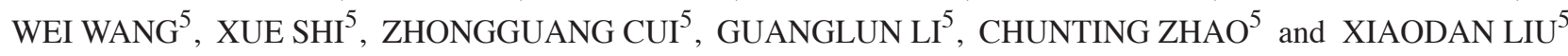 \\ ${ }^{1}$ Hematology Diagnosis Laboratory, The Affiliated Hospital of Qingdao University, Qingdao, Shandong 266003; \\ ${ }^{2}$ Department of Medicine, Qingzhou Traditional Chinese Medicine Hospital, Weifang, Shandong 262500; \\ ${ }^{3}$ Department of Hematology, Rizhao People's Hospital, Rizhao, Shandong 276800; ${ }^{4}$ Department of Hematology, \\ Jining No. 1 People's Hospital, Jining, Shandong 272011; ${ }^{5}$ Department of Hematology, The Affiliated \\ Hospital of Qingdao University, Qingdao, Shandong 266003, P.R. China
}

Received July 1,2018; Accepted April 12, 2019

DOI: $10.3892 /$ etm.2019.7660

\begin{abstract}
The current study aimed to explore the levels of leptin (LEP) and LEP receptor (LEP-R) on the progression of aplastic anemia (AA) with bone marrow fat conversion. An AA model was developed by infusing C57BL/6 lymph node cells into $\mathrm{BALB} / \mathrm{c}$ mice. At $0,3,6,9,12,15$ and 18 days after modeling, routine blood counts, bone marrow biopsy slides, lymphocyte subsets (CD4 ${ }^{+}$and $\mathrm{CD} 8^{+} \mathrm{T}$ cells) and cytokine levels [including interleukin (IL)-2, IL-4, IL-5 and interferon- $\gamma$ ] were assessed. LEP and LEP-R levels in peripheral blood serum, mesenchymal stem cells (MSCs) and bone marrow were also analyzed by enzyme-linked immunosorbent assay, polymerase chain reaction and immunohistochemistry. The relevance of LEP, LEP-R and other factors was analyzed by Pearson's correlation analysis. Peripheral pancytopenia (reduced count of white blood cells, red blood cells, hemoglobin and platelets), abnormal immune factor levels and histological changes in bone marrow sections were detected in the AA model mice, suggesting that these mice mimicked the pathological changes commonly observed in AA. In addition, following the establishment of AA, the LEP level was gradually increased and the LEP-R level was reduced in the mice over time $(\mathrm{P}<0.05)$. The expression of adipogenic genes, including CCAAT/enhancer-binding protein $(\mathrm{C} / \mathrm{EBP}) \alpha$, $\mathrm{C} / \mathrm{EBP} \beta$ and peroxisome proliferator-activated receptor $\gamma$, was markedly increased, while the expression of the osteogenic gene runt-related transcription factor 2 was reduced compared with the levels in the control group $(\mathrm{P}<0.05)$. Taken together, damage to LEP-R may lead to dysregulation of LEP and the
\end{abstract}

Correspondence to: Dr Chunting Zhao or Dr Xiaodan Liu, Department of Hematology, The Affiliated Hospital of Qingdao University, 16 Jiangsu Road, Qingdao, Shandong 266003, P.R. China E-mail: chuntingzhaoctz@163.com

E-mail: liuxiaodan8711@163.com

Key words: aplastic anemia, leptin, leptin receptor, mesenchymal stem cells enhancement of MSCs to differentiate into adipocytes, resulting in excessive fat in bone marrow of AA patients.

\section{Introduction}

Aplastic anemia (AA) is a type of acquired bone marrow failure syndrome that is associated with a high mortality rate. AA is characterized by the destruction of hematopoietic cells by the immune system, which can lead to severe anemia and pancytopenia $(1,2)$. Bone marrow biopsy results in AA have demonstrated that the bone cavity is filled with fat cells following the destruction of hematopoietic cells. Thus, marrow fat expansion may be another pathological factor of AA (3). However, the mechanism underlying the increased bone fat in AA patients is currently not well understood.

Bone marrow mesenchymal stem cells (MSCs) are a group of homogeneous cells that can differentiate into adipocytes, osteoblasts, chondrocytes, tendon cells and stellate nerve cells in the appropriate microenvironment (4). Studies have reported that MSCs synthesize and secrete various cytokines, including interleukin (IL)-6, IL-11, granulocyte-macrophage colony-stimulating factor and stem cell factor (5-7). In addition, MSCs interact with immune cells and hematopoietic stem cells to ensure normal hematopoiesis in the bone marrow. However, in AA patients, MSCs differentiate abnormally, with induction to adipocytes but decreased differentiation in osteoblasts, resulting in the conversation of bone marrow into fat, as well as altered levels of various hormonals, including leptin $(5,8)$.

Leptin (LEP) is a circulating hormone that is mainly secreted by adipose tissues, as well as a few other tissues and cells, such as the placenta, gastric mucosa, skeletal muscle and human mammary epithelial cells (9-11). LEP functions through its interaction with the LEP receptor (LEP-R), which is expressed in several cell types of the innate and adaptive immunity systems, including MSCs, and dendritic, natural killer, T and B cells (12). LEP has been recognized as an important factor for modulating the immune responses, as well as bone growth.

According to previous studies, LEP signaling is involved in the differentiation of MSCs into osteoblasts or adipogenic 
cells $(13,14)$. A previous study reported a higher level of LEP and a lower level of LEP-R in the plasma of AA patients (15). Our preliminary data identified the same tendency regarding the levels of LEP and LEP-R in the bone marrow biopsy tissue (16). Thus, in the present study, AA model mice were established to explore the role of LEP and LEP-R in the differentiation of MSCs in AA. The results of the present study offer a new perspective for the treatment of AA.

\section{Materials and methods}

Animals. A total of $70 \mathrm{BALB} / \mathrm{c}$ mice (male; weight, 18-25 g; age, 7-10 weeks) were obtained from the Experimental Animal Center of Hubei Province (Shiyan, China). Three model mice had infections and one had a serious visceral hemorrhage; these mice were humanely euthanized and removed from the study. Three mice (two in model group and one in control) that were still alive on day 18 were removed from the studies and they were excessive Therefore, only $63 \mathrm{BALB} / \mathrm{c}$ mice were assessed in the current study. A total of $10 \mathrm{C} 57 \mathrm{BL} / 6$ mice (male; weight, 25-30 g; age, 8-10 weeks) were obtained from Hunan Silaike Jingda Laboratory Animal Co., Ltd. (China). The mice were housed individually in a temperature- and light-controlled room $\left(21-23^{\circ} \mathrm{C} ; 12\right.$-h light/dark cycle) under specific pathogen-free conditions. The mice were maintained in accordance with the Guide for the Care and the Use of Laboratory Animals of the National Institutes of Health. All experiments using mice were performed according to protocols approved by the Ethics Committee of the Affiliated Hospital of Qingdao University (Qingdao, China).

Induction of AA model and specimen collection. The AA mouse model was developed by infusion of lymph node (LN) cells obtained from C57BL/6 mice into the BALB/c mice $(17,18)$. A total of $70 \mathrm{BALB} / \mathrm{c}$ mice were randomly divided into the control $(n=7$, including 1 extra mouse in case of death during the experiments) and model ( $n=56$, including $10 \%$ extra in case of death) groups. Mice in the model group were induced into immune-mediated AA as reported (19). Briefly, mice were subjected to whole-body exposure to a single dose of $4 \mathrm{~Gy}$ at a dose rate of $0.5 \mathrm{~Gy} / \mathrm{min}$ using an X-ray irradiator system in well-ventilated vinyl containers without anesthesia. After $6 \mathrm{~h}$, AA was induced in the model group through intraperitoneal injection with $1 \times 10^{6} \mathrm{LN}$ cells collected from C57BL/6 donors. After X-ray exposure, the number of hematopoietic stem cells in bone marrow decreased and the immune function was abnormal; this protocol was performed as previously described (20). After the donor lymphocytes were injected, the immune function was disturbed, the distribution and function of $\mathrm{T}$ lymphocyte subgroups were abnormal, and a large number of T cells were activated which eventually induces $\mathrm{T}$ lymphocytes to attack hematopoietic cells, inducing AA occurred; this protocol was performed as previously described (21). The LN cells included thymus, inguinal and axillary LN cells, which were disaggregated, filtered through a 200-mesh nylon filter, and then washed twice with phosphate-buffered saline (PBS) and lymphocyte separation media. The control mice were sham-irradiated, and received intraperitoneal injection of PBS and lymphocyte separation media of the same volume.
Food intake and behavior of mice were observed every day after LN cell infusion. Samples were randomly harvested from the mice on days $0,3,6,9,12,15$ and 18 after $\mathrm{LN}$ cell infusion. In total, 8 mice from the model group and 1 from the control group were examined at each time point, resulting in a total number of 63 animals tested in the two groups. Prior to sample collection, mice were fasted for $1 \mathrm{~h}$, and then blood was collected from the retro-orbital plexus under $2.5 \%$ isoflurane anesthesia, following which mice were immediately euthanized by cervical dislocation. Cardiac blood samples, as well as iliac and femur specimens that were surgically dissected, were collected for further examination. Each experiment was performed twice. The study experiments lasted for $\sim 1$ month, with a preparation period of 2 days, an experimental period of 18 days and index testing for approximately 10 days.

Complete blood count. Routine blood tests, including white blood cell (WBC), red blood cell (RBC), hemoglobin (HB) and platelet (PLT) counts, were assayed with the blood collected from the retro-orbital plexus. An automatic biochemical analyzer (Sysmex F-820 semi-automatic blood analyzer; Sysmex Corporation, Kobe, Japan) was used for these tests, according to the manufacturer's protocol.

Enzyme-linked immunosorbent assay (ELISA). Cardiac blood was centrifuged at $1,509.3 \mathrm{x} \mathrm{g}$ for $10 \mathrm{~min}$ at room temperature and the serum was extracted from the upper layer. The serum concentrations of IL-2, IL-4, IL-5, interferon (IFN)- $\gamma$, LEP and LEP-R were determined by ELISA using kits from BD Biosciences (San Diego, CA, USA). Absorbance at $450 \mathrm{~nm}$ was measured using a Wallac1420 Victor 3 reader (PerkinElmer, Inc., Wellesley, MA, USA).

Flow cytometry analysis of lymphocyte phenotype. Cardiac blood was used for lymphocyte phenotyping. Briefly, the samples were digested and washed twice with PBS. Next, approximately $1 \times 10^{6}$ cells were incubated with $50 \mu \mathrm{l}$ fluorescein isothiocyanate (FITC)-conjugated anti-CD4 and anti-CD8-phycoerythrin antibodies (cat. nos. 11-0341-81 and 11-0341-81, respectively; eBioscience; Thermo Fisher Scientific, Inc., Waltham, MA, USA) for $30 \mathrm{~min}$. Immediately after washing with PBS, the cells were analyzed by flow cytometry using a FACS Calibur flow cytometer (BD Biosciences).

Pathological observation of iliac bone tissue. Iliac bone tissues from AA model and control mice were fixed in $10 \%$ formalin at room temperature for $30 \mathrm{~min}$. Specimens were then decalcified, dehydrated, fixed with xylene at room temperature for $1 \mathrm{~h}$ and embedded in paraffin. Next, the tissues were cut into sections with a thickness of $3 \mu \mathrm{m}$, and further deparaffinized with xylene and ethanol. Finally, the sections were stained with hematoxylin-eosin (HE), and observed under a Nikon ECLIPESEE600 light microscope and Nikon camera (Nikon Corporation, Tokyo, Japan).

Immunohistochemical analysis. In the current study, the PV-9000 two-step immunohistochemical method was used to evaluate LEP-R level in slices of iliac bone tissue (22). Briefly, paraffin-embedded sections were deparaffinized and 
Table I. Primers of reverse transcription-quantitative PCR.

\begin{tabular}{|c|c|c|c|}
\hline Primers & Direction & Sequence $\left(5^{\prime}-3^{\prime}\right)$ & Size (bp) \\
\hline \multirow[t]{2}{*}{$\beta$-actin } & $\mathrm{F}$ & CACGATGGAGGGGCCGGACTCATC & 240 \\
\hline & $\mathrm{R}$ & TAAAGACCTCTATGCCAACACAG & \\
\hline \multirow[t]{2}{*}{ LEP } & $\mathrm{F}$ & ACCCTGTGCGGATTCTTGTG & 147 \\
\hline & $\mathrm{R}$ & GGAGGAGACTGACTGCGTGT & \\
\hline \multirow[t]{2}{*}{ LEP-R } & $\mathrm{F}$ & ACATACTGTTACGGTTCTGG & 175 \\
\hline & $\mathrm{R}$ & TAGCTTGTAATCACTGGGTG & \\
\hline \multirow[t]{2}{*}{$\mathrm{C} / \mathrm{EBP} \alpha$} & $\mathrm{F}$ & CCACTTGCAGTTCCAGATCG & 239 \\
\hline & $\mathrm{R}$ & CCACCGACTTCTTGGCTTTG & \\
\hline \multirow[t]{2}{*}{$\mathrm{C} / \mathrm{EBP} \beta$} & $\mathrm{F}$ & CGCCATCGACTTCAGCCCCTAC & 133 \\
\hline & $\mathrm{R}$ & CGGCTTCTTGCTCGGCTTGG & \\
\hline \multirow[t]{2}{*}{$\operatorname{PPAR} \gamma$} & $\mathrm{F}$ & TTTCAAGGGTGCCAGTTTCG & 169 \\
\hline & $\mathrm{R}$ & CATCTTTATTCATCAGGGAGGC & \\
\hline \multirow[t]{2}{*}{ Runx2 } & $\mathrm{F}$ & CTCTGGCCTTCCTCTCTCAG & 150 \\
\hline & $\mathrm{R}$ & GTAGGTAAAGGTGGCTGGGT & \\
\hline
\end{tabular}

LEP, leptin; LEP-R, leptin receptor; C/EBP, CCAAT/enhancer-binding protein; PPAR $\gamma$, peroxisome proliferator-activated receptor; Runx2, runt-related transcription factor 2 .

hydrated. Next, antigen retrieval was performed in $0.01 \mathrm{M}$ citric acid ( $\mathrm{pH} \mathrm{6.0),} \mathrm{and} \mathrm{the} \mathrm{sections} \mathrm{were} \mathrm{then} \mathrm{incubated} \mathrm{with}$ a $3 \% \mathrm{H}_{2} \mathrm{O}_{2}$ solution for $15 \mathrm{~min}$ at room temperature to block endogenous peroxidase activity. Subsequently, the sections were incubated with an anti-LEP-R antibody (cat. no. sc-8325; 1:150; Santa Cruz Biotechnology, Inc., Dallas, TX, USA) at $4^{\circ} \mathrm{C}$ overnight in a humid environment, followed by incubation with a horseradish peroxidase-labeled secondary antibody (cat. no. PV-9000; 1:50; OriGene Technologies, Inc., Beijing, China) at room temperature for $20 \mathrm{~min}$. Then chromogenic agents from the DAB chromogenic agent kit (Wuhan Boshide Biological Engineering Co., Ltd., Wuhan, China) were added to the sections. Finally, the sections were counterstained with Harris hematoxylin, dehydrated and sealed. Positive LEP-R expression was noted when the membrane presented brown-yellow staining. Sections were observed under a light microscope, and the integral optical density (IOD) of each field was measured with Image-ProPlus analysis software (version 6.0; Media Cybernetics, Inc., Rockville, MD, USA). The mean IOD value of five fields is reported as the IOD of the section.

MSC isolation, flow cytometry and reverse transcriptionquantitative polymerase chain reaction (RT-qPCR). Bone marrow-derived MSCs were obtained on days $0,3,6,9,12$, 15 and 18 after injection of LN cells. The MSCs were isolated from the bone marrow of left and right femur specimens according to the following procedure: Briefly, the femurs were broken, and bone marrow cells were shocked several times with serum-free Dulbecco's modified Eagle's medium-low glucose (Gibco; Thermo Fisher Scientific, Inc.) to collect the bone marrow fluid. Next, the cells were mixed with a syringe needle, and the cell suspension was aspirated into a centrifuge tube with a sterile pipette and centrifuged at 2,675 $\mathrm{x} \mathrm{g}$ at room temperature for $5 \mathrm{~min}$, following which the supernatant was discarded. The rest of the bone marrow cell samples
(1-2 ml) were diluted to 1:1 with RPMI-1640 medium (Gibco; Thermo Fisher Scientific, Inc.) containing 10\% fetal bovine serum (Gibco; Thermo Fisher Scientific, Inc.) and layered over Ficoll-Paque solution (Haoyang Biotechnology Co. Ltd., Tianjin, China). Cells were subsequently centrifuged at $267 \mathrm{x} \mathrm{g}$ for $10 \mathrm{~min}$ at room temperature. Then, they were placed in an $3 \mathrm{ml}$ lymphocyte separation fluid (Haoyang Biotechnology Co. Ltd., Tianjin, China) and centrifuged at 2,675 x g at room temperature for $5 \mathrm{~min}$. The milky white layer at the junction of the separator and the cell suspension was obtained as it contained the mononuclear cells. PBS was added to the mononuclear cells, which were then centrifugation at $267 \mathrm{x}$ g for $10 \mathrm{~min}$ at room temperature, and then they were washed twice with PBS. As MSCs adhere in vitro, RPMI-1640 medium was completely replaced and non-adherent cells, which were not considered to be MSCs, were removed after 3 days. When $80-85 \%$ confluence was reached, the adherent cells were detached by treatment with $0.125 \%$ trypsin and $0.1 \%$ EDTA (Sigma-Aldrich; Merck KGaA, Darmstadt, Germany), and replanted at a 1:2 dilution under the same culture conditions. At passage 4, adherent cells were identified by surface markers, using PE-conjugated CD29 (cat. no. 12-0291), CD44 (cat. no. 12-0441), CD34 (cat. no. 12-0349) and CD45 (cat. no. 12-0451) monoclonal antibodies (all 1:100; eBioscience; Thermo Fisher Scientific, Inc.) that were incubated for $30 \mathrm{~min}$ at room temperature in the dark; cells were then analyzed using a FACScan flow cytometer (BD Biosciences).

Subsequent to 4-5 passages, the MSCs were detached, and total RNA was extracted with the RNeasy Mini kit (Qiagen) according to the manufacturer's protocol. Prior to processing, RNA samples were treated with DNase I. Next, qPCR was performed using an ABI PRISM 7700 system (Applied Biosystems; Thermo Fisher Scientific, Inc.). The concentration of RNA was measured by a spectrophotometer. Reverse transcription was performed using cDNA First Chain 
A
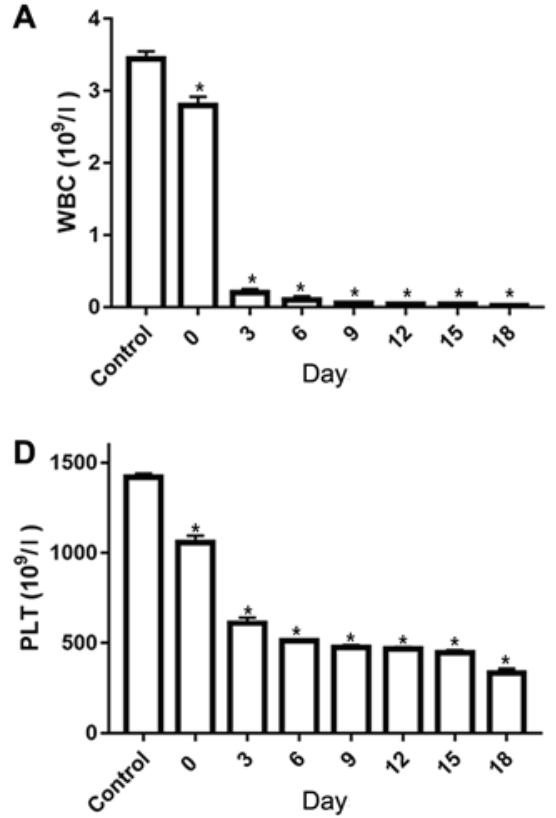

G

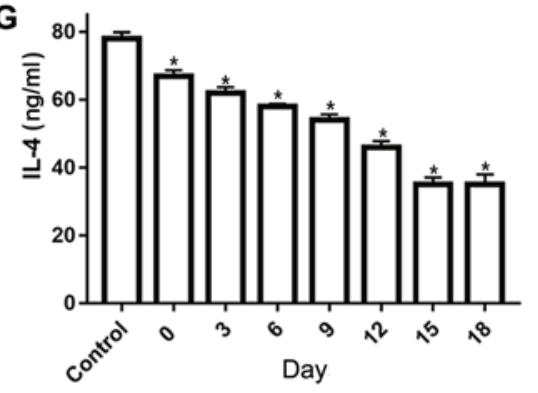

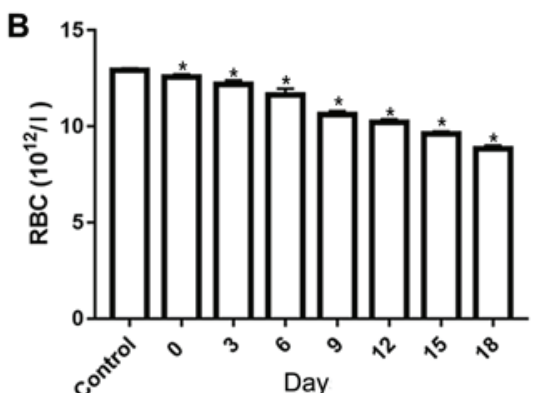
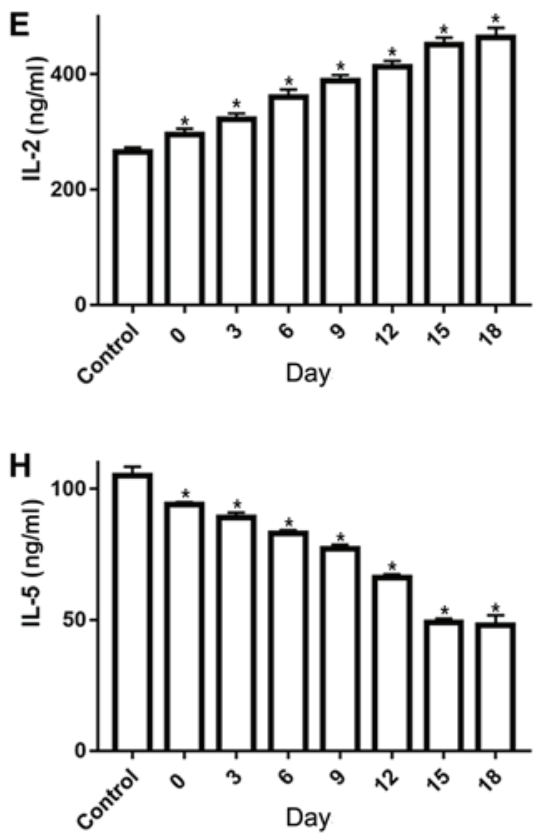
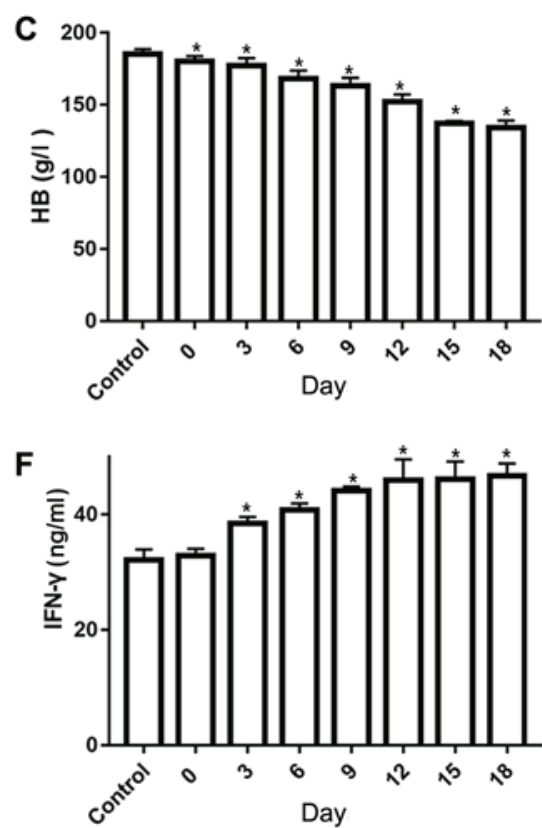

I

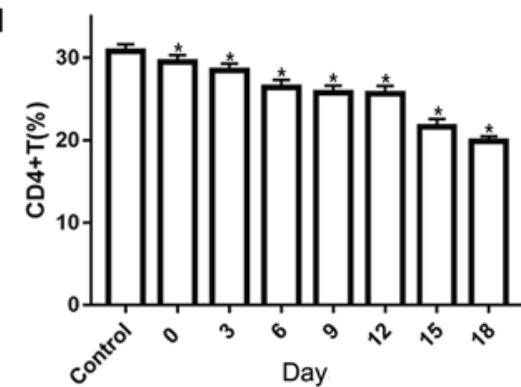

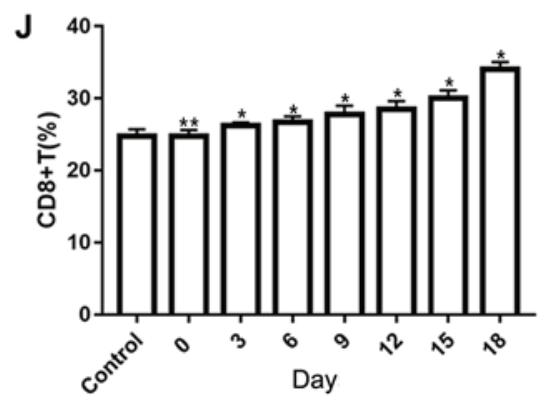

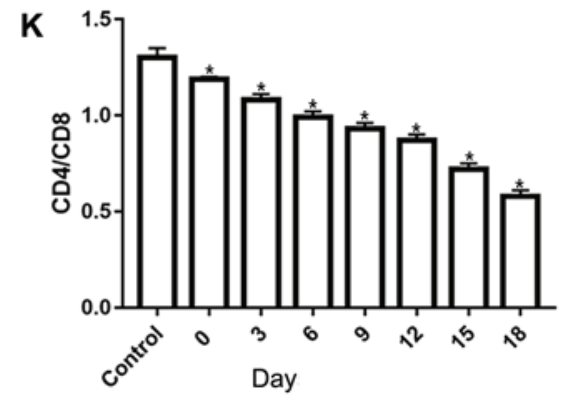

Figure 1. Results of blood routine examination and immune factor analyses in aplastic anemia mice and controls. (A) WBC, (B) RBC, (C) HB and (D) PLT counts. (E) IL-2, (F) IFN- $\gamma$, (G) IL-4 and (H) IL-5 serum levels were examined by ELISA. (I) CD4 ${ }^{+} \mathrm{T}_{\text {cell }}$ count and (J) CD8 ${ }^{+} \mathrm{T}$ cell count were examined by flow cytometry. (K) The $\mathrm{CD}^{+} / \mathrm{CD}^{+}$ratio. ${ }^{*} \mathrm{P}<0.05$ and ${ }^{* *} \mathrm{P}<0.01$. WBC, white blood cell; RBC, red blood cell; HB, hemoglobin; PLT, platelet; IL, interleukin; IFN, interferon.

Synthesis kit (Fermentas; Thermo Fisher Scientific, Inc.). The thermocycling conditions were as follows: 1 cycle of $50^{\circ} \mathrm{C}$ for $2 \mathrm{~min}$ and $95^{\circ} \mathrm{C}$ for $10 \mathrm{~min}$, followed by 40 cycles of $95^{\circ} \mathrm{C}$ for $30 \mathrm{sec}$ and $60^{\circ} \mathrm{C}$ for $30 \mathrm{sec}$. The data was analyzed with $2^{-\Delta \Delta C t}(23)$. The primers used for $\beta$-actin, LEP, LEP-R, CCAAT/enhancer-binding protein $(\mathrm{C} / \mathrm{EBP}) \alpha$, peroxisome proliferator-activated receptor $\gamma$ (PPAR $\gamma)$ and runt-related transcription factor 2 (Runx2) are listed in Table I.

Statistical analysis. All data are expressed as the mean \pm standard deviation, and were analyzed using SPSS statistical software, version 17.0 (SPSS, Inc., Chicago, IL,
USA). Normal distribution and homogeneity tests were used for measurement data. The results of blood routine tests, serum concentrations (IL-2, IL-4, IL-5, IFN- $\gamma$, LEP and LEP-R), lymphocyte phenotype, LEP-R expression in iliac bone marrow and MSC-associated genes (LEP, LEP-R, C/EBP $\alpha$, PPAR $\gamma$ and Runx2) were compared between the control and model groups using analysis of variance (parametric) or Kruskal-Wallis test (non-parametric), as appropriate. Bivariate correlation analysis with Pearson's correlation coefficient was used to explore the direction and degree of the correlation between two factors. Comparisons with a probability value of $\mathrm{P}<0.05$ were considered to be statistically significant. 
Table II. Comparison of cytokine levels ( $\mathrm{ng} / \mathrm{ml}$; mean \pm standard deviation) in different groups.

\begin{tabular}{|c|c|c|c|c|c|}
\hline Group & $\mathrm{n}$ & IL-2 & IFN- $\gamma$ & IL-4 & IL-5 \\
\hline Control & 8 & $265.7 \pm 7.55$ & $32.12 \pm 1.83$ & $78.89 \pm 1.87$ & $105.84 \pm 3.38$ \\
\hline \multicolumn{6}{|l|}{ Model } \\
\hline 0 days & 8 & $295.13 \pm 10.32^{\mathrm{a}}$ & $32.91 \pm 1.14$ & $67.30 \pm 1.67^{\mathrm{a}}$ & $94.26 \pm 0.89^{a}$ \\
\hline 3 days & 8 & $322.56 \pm 9.74^{\mathrm{a}}$ & $38.49 \pm 1.11^{\mathrm{a}}$ & $62.68 \pm 1.61^{\mathrm{a}}$ & $89.31 \pm 1.92^{\mathrm{a}}$ \\
\hline 6 days & 8 & $360.18 \pm 13.41^{\mathrm{a}}$ & $40.82 \pm 1.10^{\mathrm{a}}$ & $58.28 \pm 0.78^{a}$ & $83.18 \pm 1.22^{\mathrm{a}}$ \\
\hline 9 days & 8 & $389.40 \pm 9.49^{\mathrm{a}}$ & $44.10 \pm 0.76^{\mathrm{a}}$ & $54.87 \pm 1.64^{\mathrm{a}}$ & $77.48 \pm 1.58^{\mathrm{a}}$ \\
\hline 12 days & 8 & $413.17 \pm 10.14^{\mathrm{a}}$ & $45.96 \pm 3.61^{\mathrm{a}}$ & $46.00 \pm 1.76^{\mathrm{a}}$ & $66.78 \pm 1.30^{\mathrm{a}}$ \\
\hline 15 days & 8 & $451.06 \pm 12.38^{\mathrm{a}}$ & $46.14 \pm 3.04^{\mathrm{a}}$ & $35.73 \pm 2.10^{\mathrm{a}}$ & $49.48 \pm 1.43^{\mathrm{a}}$ \\
\hline 18 days & 8 & $464.15 \pm 16.64^{\mathrm{a}}$ & $46.17 \pm 2.13^{\mathrm{a}}$ & $35.14 \pm 3.00^{\mathrm{a}}$ & $48.24 \pm 3.75^{\mathrm{a}}$ \\
\hline
\end{tabular}

${ }^{\text {aP }}<0.01$, vs. control group. LEP, leptin; LEP-R, leptin receptor; IL, interleukin; IFN- $\gamma$, interferon $\gamma$.

\section{Results}

General state of mice. Mice in the control group exhibited no evident decrease in activity or any other physical changes. Subsequent to injection with the LN cells, mice in the model group exhibited different degrees of weight loss, activity reduction, lassitude, piloerection, eye closure and arched backs.

Identification of the AA model. Infusion of $1 \times 10^{6} \mathrm{LN}$ cells into BALB/c mice induced pancytopenia. On average, the number of WBCs was reduced by $\sim 3$-fold as compared with the count in control mice (Fig. 1A). In addition, 0.5- to 3-fold reductions were observed in RBC count, HB level and PLT count in the AA model mice (Fig. 1B-D). Analysis of the immune system function indicated that the AA model mice had significantly higher serum IFN- $\gamma$ and IL-2 levels at 3, 6, 9, 12, 15 and 18 days, and IL-2 levels were also significantly higher at 0 day when compared with control mice $(\mathrm{P}<0.05$; Fig. $1 \mathrm{E}$ and $\mathrm{F})$. By contrast, serum IL-4 and IL-5 levels were significantly lower in AA model mice in comparison with those in untreated mice $(\mathrm{P}<0.05$; Fig. $1 \mathrm{G}$ and $\mathrm{H}$; Table II). The lymphocyte phenotype was also examined, and as expected, the AA mice exhibited a greater percentage of $\mathrm{CD}^{+} \mathrm{T}$ cells and reduced $\mathrm{CD} 4^{+} \mathrm{T}$ cells in their bone marrow (Fig. 1I-K). Furthermore, histological examination of bone marrow samples from the AA mice at $0,3,6,9,12,15$ and 18 days (Fig. 2B-H) demonstrated various degrees of hypocellularity and empty marrow replaced by globules of fat when compared with the normal cellularity observed in control mice (Fig. 2A).

Expression of serum LEP (sLEP) and serum soluble LEP-R $(s L E P-R)$. Following the injection of the cells, sLEP levels in mice were significantly elevated in a time-dependent manner compared with the levels in control mice, while sLEP-R levels were markedly decreased ( $\mathrm{P}<0.01$; Table III). In addition, as shown in Table IV, the changes in SLEP and SLEP-R levels were closely associated with the changes in the levels of immune factors and various indicators in the blood $(\mathrm{P}<0.01)$. Changes in sLEP levels were negatively correlated with IL-2 and IFN- $\gamma$, but positively correlated with other factors. Changes in SLEP were positively correlated with IL-2 and IFN- $\gamma(r>0)$, whereas they were negatively corrected with other factors $(r<0)$. By
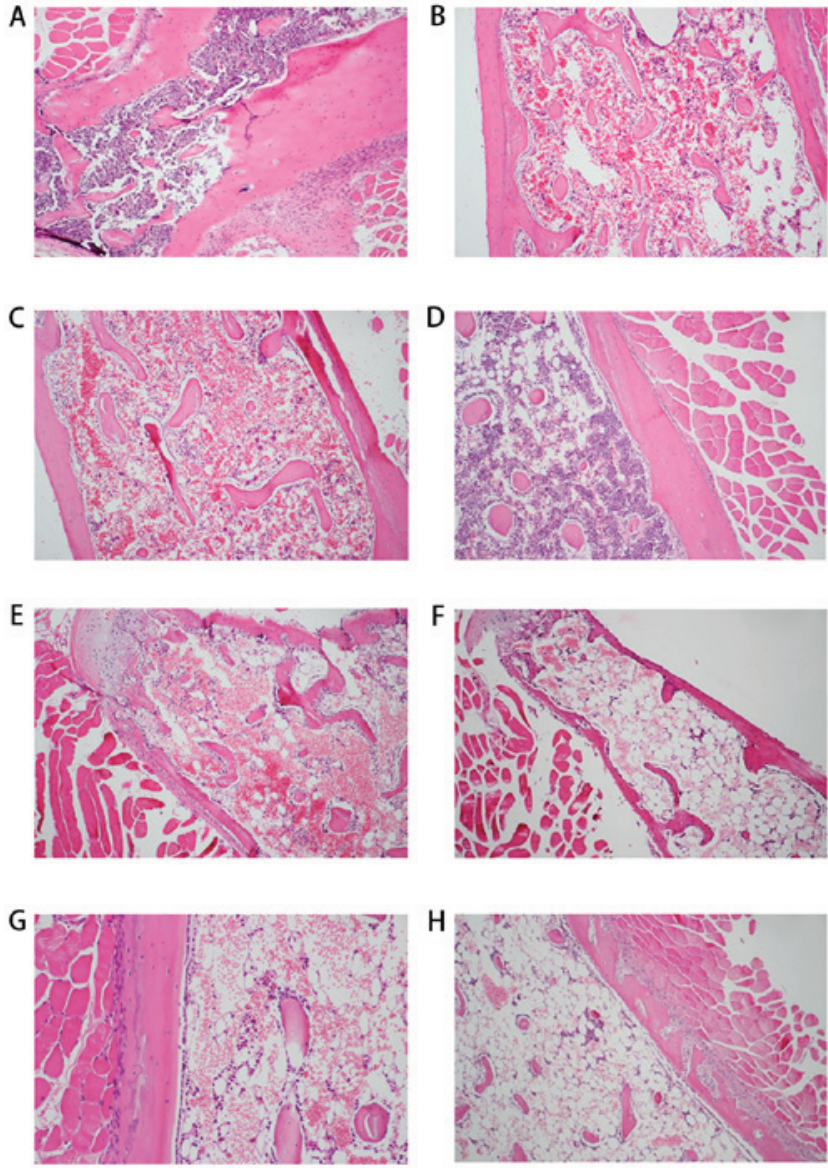

Figure 2.Figure 2. Histological structure of bone marrow, examined by hematoxylineosin staining in: (A) Control and aplastic anemia model mice at (B) 0 days, (C) 3 days, (D) 6 days, (E) 9 days, (F) 12 days, (G) 15 days and $(\mathrm{H}) 18$ days after infusion of lymph node cells. Morphological and cytological changes were observed in mice with induced bone marrow failure.

contrast, sLEP-R was negatively corrected with IL-2 and IFN- $\gamma$, and positively correlated with other factors $(r<0)$.

LEP-R levels in iliac bone marrow, as measured by immunohistochemistry. Analysis of iliac bone marrow sections revealed cytoplasmic localization of LEP-R with microgranular 
Table III. Comparison of sLEP and sLEP-R levels using ELISA.

\begin{tabular}{lccc}
\hline Group & $\mathrm{n}$ & LEP $(\mathrm{ng} / \mathrm{ml})$ & sLEP-R $(\mathrm{ng} / \mathrm{ml})$ \\
\hline Control & 8 & $4.16 \pm 0.05$ & $7.47 \pm 0.10$ \\
Model & & & \\
0 days & 8 & $4.33 \pm 0.13^{\mathrm{a}}$ & $7.04 \pm 0.10^{\mathrm{a}}$ \\
3 days & 8 & $4.62 \pm 0.17^{\mathrm{a}}$ & $6.62 \pm 0.12^{\mathrm{a}}$ \\
6 days & 8 & $5.19 \pm 0.12^{\mathrm{a}}$ & $6.25 \pm 0.13^{\mathrm{a}}$ \\
9 days & 8 & $5.37 \pm 0.09^{\mathrm{a}}$ & $5.67 \pm 0.13^{\mathrm{a}}$ \\
12 days & 8 & $5.79 \pm 0.12^{\mathrm{a}}$ & $4.98 \pm 0.16^{\mathrm{a}}$ \\
15 days & 8 & $6.30 \pm 0.06^{\mathrm{a}}$ & $4.28 \pm 0.13^{\mathrm{a}}$ \\
18 days & 8 & $6.33 \pm 0.29^{\mathrm{a}}$ & $4.18 \pm 0.10^{\mathrm{a}}$ \\
\hline
\end{tabular}

${ }^{a} \mathrm{P}<0.01$ vs. control group. Data are presented as mean \pm standard deviation. sLEP, serum leptin; sLEP-R, serum leptin receptor.

Table IV. Analysis of the association of LEP and LEP-R levels with immune and blood indices.

\begin{tabular}{lccccc}
\hline & \multicolumn{2}{c}{ LEP } & & \multicolumn{2}{c}{ LEP-R } \\
\cline { 2 - 3 } \cline { 5 - 6 } Parameter & r-value & P-value & & r-value & P-value \\
\hline IL-2 & 0.973 & $<0.01$ & & -0.974 & $<0.01$ \\
IFN- $\gamma$ & 0.884 & $<0.01$ & & -0.888 & $<0.01$ \\
IL-4 & -0.960 & $<0.01$ & & 0.983 & $<0.01$ \\
IL-5 & -0.957 & $<0.01$ & & 0.987 & $<0.01$ \\
CD4 ${ }^{+}$CD8 ${ }^{+}$ & -0.956 & $<0.01$ & & 0.966 & $<0.01$ \\
WBC & -0.837 & $<0.01$ & & 0.863 & $<0.01$ \\
RBC & -0.955 & $<0.01$ & & 0.978 & $<0.01$ \\
HB & -0.934 & $<0.01$ & & 0.959 & $<0.01$ \\
PLT & -0.824 & $<0.01$ & & 0.821 & $<0.01$ \\
\hline
\end{tabular}

LEP, leptin; LEP-R, leptin receptor; IL, interleukin; IFN, interferon; WBC, white blood cell; RBC, red blood cell; HB, hemoglobin; PLT, platelet; CD, cluster of differentiation.

staining. All samples examined were stained positive for LEP-R. In control mice, homogeneous immunoreactivity was observed (Fig. 3A), whereas in the AA model mice, the LEP-R distribution was heterogeneous (Fig. 3B-D), and LEP-R levels declined in a time-depended manner (Fig. 3E; Table V).

Expression levels of $L E P, L E P-R, C / E B P \alpha, C / E B P \beta, P P A R \gamma$ and Runx 2 genes in MSCs. Bone marrow-derived MSCs were harvested at passage 4 to analyze their immunophenotype using flow cytometry. The expression of CD29 $(91.98 \pm 0.07 \%)$ and CD44 $(90.98 \pm 0.11 \%)$ was reported, whereas lack of CD34 $(4.98 \pm 0.08 \%)$ and CD45 (5.97 $\pm 0.09 \%$ ) expression was observed (Fig. 4).

Furthermore, the expression levels of LEP, LEP-R, C/EBP $\alpha$, $\mathrm{C} / \mathrm{EBP} \beta, \mathrm{PPAR} \gamma$ and Runx 2 genes in the bone marrow-derived MSCs were examined. The LEP and LEP-R expression levels in MSCs after infusion of LN cells are displayed in Fig. 5A.
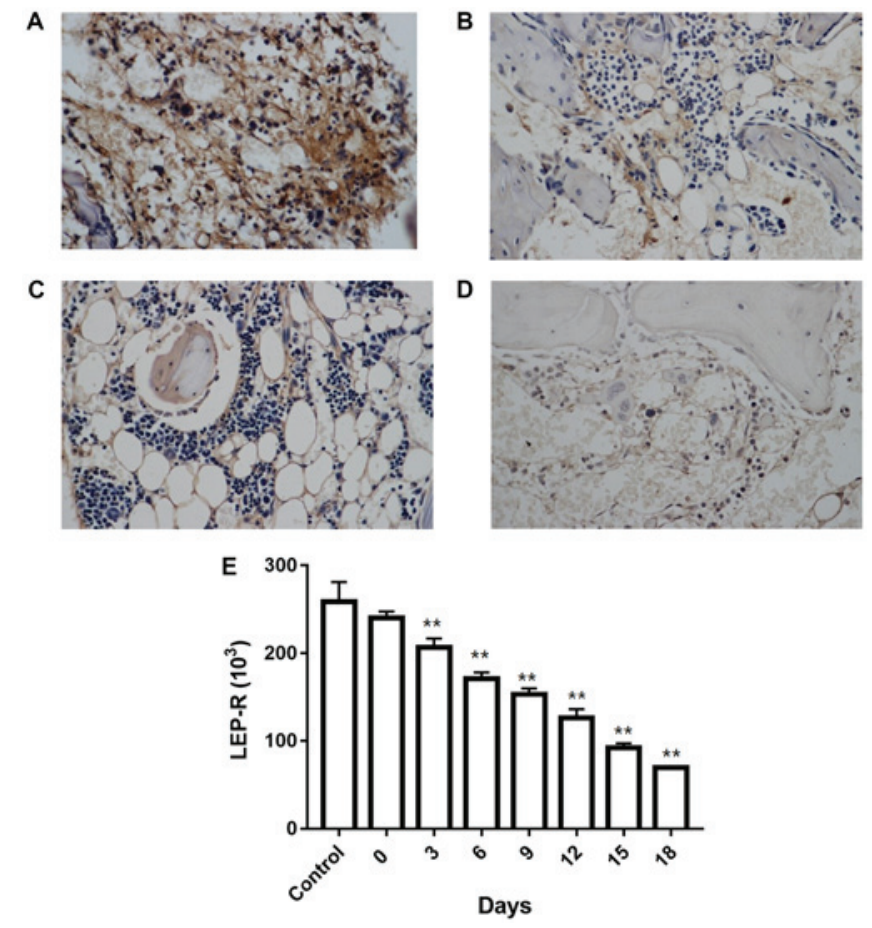

Figure 3. Immunohistochemical analysis of LEP-R levels in the bone marrow of: (A) Control mice; and AA model mice at (B) 6 days, (C) 12 days and (D) 18 days after infusion of lymph node cells. (E) Changes in LEP-R levels in the AA model mice. ${ }^{* *} \mathrm{P}<0.01$ vs. control group. LEP-R, leptin receptor; AA, aplastic anemia.

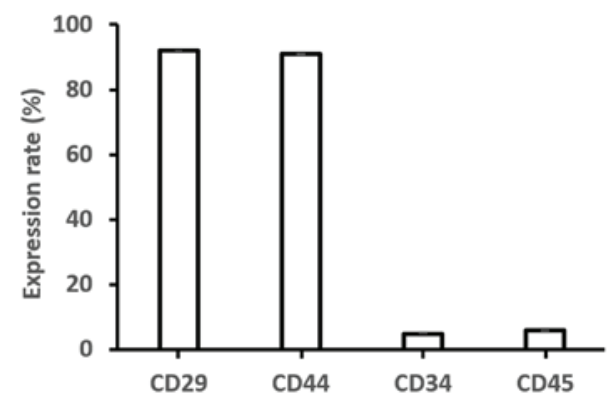

Figure 4. Expression of CD29, CD44, CD34 and CD45 in mesenchymal stem cells. Protein expression levels were assessed by flow cytometry. CD, cluster of differentiation.

The MSC samples from all tested AA model mice expressed high levels of LEP at 6, 9, 12, 15, 18 days compared with the control group $(\mathrm{P}<0.01$; Table VI). In contrast, injection with the LN cells induced an evident decline in LEP-R levels at $3,6,9,12,15,18$ days compared with the control group $(\mathrm{P}<0.01$; Table VII). In addition, the expression levels of the adipogenic genes $\mathrm{C} / \mathrm{EBP} \alpha, \mathrm{C} / \mathrm{EBP} \beta$ and PPAR $\gamma$ exhibited gradual upward trends from day 6-18 (Tables VIII-X), while the expression of the osteogenic gene Runx2 was significantly decreased at 3,6, $9,12,15,18$ days compared with the con $\varsigma$ trol $(\mathrm{P}<0.01$; Fig. 5B; Table XI). These results suggest that an increasing number of MSCs in the bone marrow were converted to fat cells.

Correlation of LEP and LEP-R with the expression of osteogenic and adipogenic genes. Based on bivariate correlation analysis with Pearson's correlation coefficient, LEP levels were 
Table V. LEP-R levels in iliac bone marrow tissue.

\begin{tabular}{lcc}
\hline Group & $\mathrm{n}$ & LEP-R $\left(\times 10^{3}\right)$ \\
\hline Control & 6 & $258.85 \pm 22.15$ \\
Model & & \\
0 days & 6 & $240.28 \pm 7.39$ \\
3 days & 6 & $206.80 \pm 10.15^{\mathrm{a}}$ \\
6 days & 6 & $171.23 \pm 7.03^{\mathrm{a}}$ \\
9 days & 6 & $153.74 \pm 6.66^{\mathrm{a}}$ \\
12 days & 6 & $126.22 \pm 9.99^{\mathrm{a}}$ \\
15 days & 6 & $91.93 \pm 5.25^{\mathrm{a}}$ \\
18 days & 6 & $69.48 \pm 1.75^{\mathrm{a}}$ \\
\hline
\end{tabular}

${ }^{\mathrm{a}} \mathrm{P}<0.01$ vs. control group. Data are presented as mean \pm standard deviation. LEP-R, leptin receptor.

Table VI. Leptin level in bone marrow mesenchymal stem cells.

\begin{tabular}{lcccc}
\hline Group & $\mathrm{n}$ & $2^{-\Delta \Delta \mathrm{Ct}}$ & $\mathrm{t}$-value & P-value \\
\hline Control & 8 & 1.00 & - & - \\
Model & & & & \\
0 days & 8 & 1.10 & 1.39 & 0.19 \\
3 days & 8 & 1.14 & 2.65 & 0.07 \\
6 days & 8 & 1.22 & 4.12 & $<0.01$ \\
9 days & 8 & 1.37 & 8.25 & $<0.01$ \\
12 days & 8 & 1.44 & 9.67 & $<0.01$ \\
15 days & 8 & 1.61 & 14.72 & $<0.01$ \\
18 days & 8 & 1.78 & 16.05 & $<0.01$ \\
\hline
\end{tabular}

Table VII. Leptin receptor level in bone marrow mesenchymal stem cells.

\begin{tabular}{lcccc}
\hline Group & $\mathrm{n}$ & $2^{-\Delta \Delta \mathrm{Ct}}$ & $\mathrm{t}$-value & P-value \\
\hline Control & 8 & 1.00 & - & - \\
Model & & & & \\
0 days & 8 & 0.91 & -2.05 & 0.07 \\
3 days & 8 & 0.80 & -5.87 & $<0.01$ \\
6 days & 8 & 0.68 & -9.80 & $<0.01$ \\
9 days & 8 & 0.63 & -9.60 & $<0.01$ \\
12 days & 8 & 0.46 & -20.95 & $<0.01$ \\
15 days & 8 & 0.36 & -24.11 & $<0.01$ \\
18 days & 8 & 0.29 & -25.96 & $<0.01$ \\
\hline
\end{tabular}

significantly positively correlated with the expression levels of $\mathrm{C} / \mathrm{EBP} \alpha, \mathrm{C} / \mathrm{EBP} \beta$ and PPAR $\gamma(\mathrm{r}>0 ; \mathrm{P}<0.01)$, and negatively correlated with the expression of Runx2 $(\mathrm{r}<0 ; \mathrm{P}<0.01)$. By contrast, LEP-R expression was negatively correlated with the expression of the adipogenic genes $(\mathrm{C} / \mathrm{EBP} \alpha, \mathrm{C} / \mathrm{EBP} \beta$ and
Table VIII. CCAAT/enhancer-binding protein $\alpha$ gene expression level in iliac bone marrow tissue.

\begin{tabular}{lcccc}
\hline Group & $\mathrm{n}$ & $2^{-\Delta \Delta \mathrm{Ct}}$ & $\mathrm{t}$-value & P-value \\
\hline Control & 6 & 1.00 & - & - \\
Model & & & & \\
0 days & 6 & 1.10 & 2.22 & 0.05 \\
3 days & 6 & 1.15 & 2.81 & 0.02 \\
6 days & 6 & 1.19 & 3.98 & $<0.01$ \\
9 days & 6 & 1.39 & 5.64 & $<0.01$ \\
12 days & 6 & 1.43 & 5.81 & $<0.01$ \\
15 days & 6 & 1.60 & 9.00 & $<0.01$ \\
18 days & 6 & 1.68 & 9.85 & $<0.01$ \\
\hline
\end{tabular}

PPAR $\gamma$ ) and positively correlated with the osteogenic gene Runx2 (P<0.01; Table XII).

\section{Discussion}

Abnormal immunity and damage to hematopoietic stem/progenitor cells mediated by the immune system are major factors in the pathogenesis of AA $(24,25)$. In the present study, an AA animal model was established by infusion of LN cells into BALB/c mice, which was similar to graft-versus-host disease (26). A relatively low dosage of X-ray was used in the experiments of the present study to ensure longer survival of mice. In our preliminary experiments (data not shown), the $\mathrm{X}$-ray dosages of 2.0, 4.0 and 6.0 Gy were assessed, and the dose of 4.0 Gy was finally selected since this exposure caused a notable decrease in blood routine indices, but fewer mice died from hematopenia. In further preliminary experiments, normal mice were exposed to $4.0 \mathrm{~Gy}$ of X-ray radiation alone, and the blood- and bone-associated indices were examined after 10 days. It was observed that the general state, blood routine results, LEP, LEP-R and bone marrow sections were not significantly different from those of the control mice ( $P>0.05$; data are not shown). Thus, it can be inferred that 4.0-Gy X-ray radiation may be suitable for modeling, without causing a marked number of cells to die in the bone marrow.

The typical characteristics of AA, including severe anemia and pancytopenia with decreased WBC, RBC, HB and PLT counts, were observed in the present study after LN cell infusion (2). Activated $\mathrm{CD}^{+} \mathrm{T}$ cells and an unbalanced $\mathrm{CD} 4^{+} / \mathrm{CD}^{+}$ ratio were also observed in the AA mice. As expected, different degrees of changes in IL-2, IL-4, IL-5 and IFN- $\gamma$ levels were observed. These immune molecules may comprise a cytokine network that damages hematopoietic stem/progenitor cells, MSCs and angioblasts/endothelial progenitor cells (4). Combined with the histological alterations observed in bone sections, these results indicate that BALB/c mice infused with LN cells truly mimicked the pathological changes in AA, and are appropriate mouse models for studying the underlying mechanism.

Fat conversion of bone marrow is common in patients with AA, and fat cells are considered to fill the void left after the destruction of hematopoietic cells. As described in earlier 

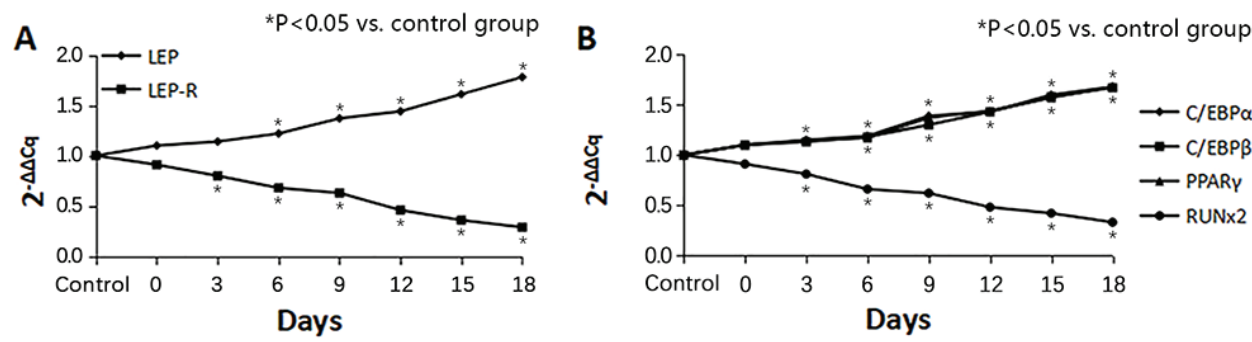

Figure 5. (A) LEP and LEP-R levels in the mesenchymal stem cells of aplastic anemia model mice. (B) Expression levels of adipogenic and osteogenic genes. ${ }^{*} \mathrm{P}<0.05$. LEP, leptin; LEP-R, leptin receptor.

Table IX.CCAAT/enhancer-binding protein $\beta$ gene expression level in iliac bone marrow tissue.

\begin{tabular}{lcccc}
\hline Group & $\mathrm{n}$ & $2^{-\Delta \Delta \mathrm{Ct}}$ & $\mathrm{t}$-value & P-value \\
\hline Control & 8 & 1.00 & - & - \\
Model & & & & \\
0 days & 8 & 1.10 & 1.58 & 0.15 \\
3 days & 8 & 1.13 & 2.30 & 0.05 \\
6 days & 8 & 1.18 & 2.67 & 0.02 \\
9 days & 8 & 1.30 & 4.11 & $<0.01$ \\
12 days & 8 & 1.43 & 5.61 & $<0.01$ \\
15 days & 8 & 1.58 & 7.49 & $<0.01$ \\
18 days & 8 & 1.67 & 8.88 & $<0.01$ \\
\hline
\end{tabular}

Table X. Peroxisome proliferator-activated receptor $\gamma$ gene expression level in iliac bone marrow tissue.

\begin{tabular}{lcccc}
\hline Group & $\mathrm{n}$ & $2^{-\Delta \Delta \mathrm{Ct}}$ & t-value & P-value \\
\hline Control & 8 & 1.00 & - & - \\
Model & & & & \\
0 days & 8 & 1.10 & 1.61 & 0.14 \\
3 days & 8 & 1.14 & 1.79 & 0.10 \\
6 days & 8 & 1.17 & 3.20 & 0.01 \\
9 days & 8 & 1.37 & 5.26 & $<0.01$ \\
12 days & 8 & 1.44 & 6.15 & $<0.01$ \\
15 days & 8 & 1.57 & 9.05 & $<0.01$ \\
18 days & 8 & 1.68 & 11.60 & $<0.01$ \\
\hline
\end{tabular}

studies, the process of adipogenesis competes with osteogenesis, resulting in the differentiation of MSCs into adipocytes over osteoblasts, with altered levels of various hormones, such as LEP (27-29). It is well known that LEP is involved in immune regulation, inflammatory responses and hematopoiesis. More specifically, LEP can affect the development and maturation of lymphocytes in bone marrow and inhibit the apoptosis of T and B lymphocytes (30,31). Fernández-Riejos et al (32) and Du et al (33) reported that LEP induce the differentiation of T lymphocytes into T-helper 1 cells, which produce increased IL-2 and IFN- $\gamma$. This is consistent with the observations of
Table XI. Runt-related transcription factor 2 gene expression level in iliac bone marrow tissue.

\begin{tabular}{lcccc}
\hline Group & $\mathrm{n}$ & $2^{-\Delta \Delta \mathrm{Ct}}$ & $\mathrm{t}$-value & P-value \\
\hline Control & 8 & 1.00 & - & - \\
Model & & & & \\
0 days & 8 & 0.91 & -1.40 & 0.19 \\
3 days & 8 & 0.81 & -4.64 & 0.01 \\
6 days & 8 & 0.66 & -6.16 & $<0.01$ \\
9 days & 8 & 0.62 & -6.97 & $<0.01$ \\
12 days & 8 & 0.48 & -13.37 & $<0.01$ \\
15 days & 8 & 0.42 & -11.85 & $<0.01$ \\
18 days & 8 & 0.33 & -20.82 & $<0.01$ \\
\hline
\end{tabular}

Table XII. Correlation analysis of LEP and LEP-R expression on bone marrow mesenchymal stem cell surface with the expression of osteogenic and adipogenic genes.

\begin{tabular}{lccccc}
\hline & \multicolumn{2}{c}{ LEP } & & \multicolumn{2}{c}{ LEP-R } \\
\cline { 2 - 3 } \cline { 5 - 6 } Gene & r-value & P-value & & r-value & P-value \\
\hline C/EBP $\alpha$ & 0.780 & $<0.01$ & & -0.840 & $<0.01$ \\
C/EBP $\beta$ & 0.810 & $<0.01$ & & -0.869 & $<0.01$ \\
PPAR $\gamma$ & 0.779 & $<0.01$ & & -0.828 & $<0.01$ \\
Runx2 & -0.870 & $<0.01$ & & 0.947 & $<0.01$ \\
\hline
\end{tabular}

LEP, leptin; LEP-R, leptin receptor; Runx2, runt-related transcription factor 2; PPAR $\gamma$, peroxisome proliferator-activated receptor $\gamma$; $\mathrm{C} / \mathrm{EBP}, \mathrm{CCAAT} / \mathrm{enhancer-binding} \mathrm{protein.}$

the current study in AA patients, and suggests that LEP not only regulates immune responses by directly acting on mature immune cells in the peripheral blood, but also participate in the regulation of hematopoiesis by affecting lymphoid and granulocyte differentiation.

In the present study, it was observed that LEP levels were increased and LEP-R levels were decreased in the peripheral blood and bone marrow of the AA model mice. With the gradual decline of bone marrow hematopoietic capacity, LEP levels increased, and the changes in these two 
parameters were negatively correlated. The gradual increase in LEP levels was positively correlated with the transformation of T cells, suggesting that LEP may aggravate immune damage $(31,34)$. The increase in LEP levels and the decreased in the $\mathrm{CD}^{+} / \mathrm{CD}^{+}$ratio were positive correlated, which also suggests that LEP increased T cell function disorder (35). LEP damage $(30,33)$. The increase in LEP levels and the decreased in the $\mathrm{CD}^{+} / \mathrm{CD}^{+}$ratio were positive correlated, which also suggests that LEP increased T cell function disorder (34). LEP can regulate fat metabolism by promoting the osteogenic differentiation and inhibiting the adipogenic differentiation of MSCs (36). Theoretically, the number of fat cells in the bone marrow of the AA mice should be reduced by LEP; however, in the bone marrow microenvironment of the AA mice, LEP does not regulate the osteogenic and adipogenic differentiation of MSCs. The present study also observed that LEP-R levels decreased over time. Therefore, it can be speculated that the adipogenic differentiation of MSCs was enhanced, and that LEP-R was destroyed by immune injury or other causes, leading to increased LEP levels.

The adipogenic differentiation of MSCs is regulated by a sophisticated gene regulation mechanism. $\mathrm{C} / \mathrm{EBP} \beta, \mathrm{C} / \mathrm{EBP} \alpha$ and PPAR $\gamma$ participate in a regulatory cascade during adipogenesis, and serve key roles in cell growth, differentiation and homeostasis (37). Furthermore, RUNX2 is a multifunctional transcription factor that controls skeletal development by regulating chondrocyte and osteoblast differentiation (38). In the present study, overexpression of the adipogenic genes $\mathrm{C} / \mathrm{EBP} \beta, \mathrm{C} / \mathrm{EBP} \alpha$ and PPAR $\gamma$, as well as reduced expression of RUNX2, confirmed the conversion of MSCs into fat cells.

However, the current study has certain limitations. Firstly, mice rather than rats were used in the experiments, despite the potentially better simulation of the AA pathology in rats, given certain tolerances and more tissues for testing. Secondly, the animal model was more relevant for the analysis of acute AA and may not be a study of chronic AA. To this end, a rat model will be used in future studies to detect in more detail how the MSC function on adipogenic differentiation would change via X-ray irradiation or LN infusion alone. Thirdly, the number of mice was low, which may potentially result in inaccuracies of the results. Furthermore, LEP-R levels will be artificially altered to investigate the differentiation of MSCs.

In conclusion, increased LEP levels and decreased LEP-R levels were detected in the peripheral blood and MSCs of AA mice in the present study. It is speculated that the high levels of LEP may increase the immune injury in the AA mice. In addition, the decrease in LEP-R levels may contribute to the failure of LEP to regulate the differentiation of MSCs into osteoblasts, leading to the increase of fat cells in the bone marrow of AA mice.

\section{Acknowledgements}

Not applicable.

\section{Funding}

The present study was funded by the National Natural Science Foundation (grant no. H0806).

\section{Availability of data and materials}

All data generated or analyzed during the present study are included in this manuscript.

\section{Authors' contributions}

XDL and CTZ conceived of and designed the study. XCY, JY, JZ, HGZ and WW performed the experiments. YHL, CLX, XS and GLL analyzed the data. XCY, ZGC, and XDL wrote the paper. All authors read and approved the manuscript.

\section{Ethics approval and consent to participate}

All experiments using mice were performed according to protocols approved by the Ethics Committee of the Affiliated Hospital of Qingdao University (Qingdao, China).

\section{Patient consent for publication}

Not applicable.

\section{Competing interests}

The authors declare that they have no competing interests.

\section{References}

1. Scheinberg P and Young NS: How I treat acquired aplastic anemia. Blood 120: 1185-1196, 2012.

2. Scheinberg P and Chen J: Aplastic anemia: What have we learned from animal models and from the clinic. Semin Hematol 50: 156-164, 2013.

3. Bredella MA, Fazeli PK, Miller KK, Misra M, Torriani M, Thomas BJ, Ghomi RH, Rosen CJ and Klibanski A: Increased bone marrow fat in anorexia nervosa. J Clin Endocrinol Metab 94: 2129-2136, 2009.

4. Ng F, Boucher S, Koh S, Sastry KS, Chase L, Lakshmipathy U, Choong C, Yang Z, Vemuri MC, Rao MS and Tanavde V: PDGF, TGF-beta, and FGF signaling is important for differentiation and growth of mesenchymal stem cells (MSCs): Transcriptional profiling can identify markers and signaling pathways important in differentiation of MSCs into adipogenic, chondrogenic, and osteogenic lineages. Blood 112: 295-307, 2008.

5. Majumdar MK, Thiede MA, Haynesworth SE, Bruder SP and Gerson SL: Human marrow-derived mesenchymal stem cells (MSCs) express hematopoietic cytokines and support long-term hematopoiesis when differentiated toward stromal and osteogenic lineages. J Hematother Stem Cell Res 9: 841-848, 2000 .

6. Prockop DJ: 'Stemness' does not explain the repair of many tissues by mesenchymal stem/multipotent stromal cells (MSCs). Clin Pharmacol Ther 82: 241-243, 2007.

7. Zhou BO, Yu H, Yue R, Zhao Z, Rios JJ, Naveiras O and Morrison SJ: Bone marrow adipocytes promote the regeneration of stem cells and haematopoiesis by secreting SCF. Nat Cell Biol 19: 891-903, 2017.

8. Li J, Yang S, Lu S, Zhao H, Feng J, Li W, Ma F, Ren Q, Liu B, Zhang L, et al: Differential gene expression profile associated with the abnormality of bone marrow mesenchymal stem cells in aplastic anemia. PLoS One 7: e47764, 2012.

9. Masuzaki H, Ogawa Y, Sagawa N, Hosoda K, Matsumoto T, Mise H, Nishimura H, Yoshimasa Y, Tanaka I, Mori T and Nakao K: Nonadipose tissue production of leptin: Leptin as a novel placenta-derived hormone in humans. Nat Med 3: 1029-1033, 1997.

10. Bado A, Levasseur S, Attoub S, Kermorgant S, Laigneau JP, Bortoluzzi MN, Moizo L, Lehy T, Guerre-Millo M, Le Marchand-Brustel Y and Lewin MJ: The stomach is a source of leptin. Nature 394: 790-793, 1998. 
11. Smith-Kirwin SM, O'Connor DM, De Johnston J, Lancey ED, Hassink SG and Funanage VL: Leptin expression in human mammary epithelial cells and breast milk. J Clin Endocrinol Metab 83: 1810-1810, 1998.

12. Lee NJ, Wong IP, Baldock PA and Herzog H: Leptin as an endocrine signal in bone. Curr Osteoporosis Rep 6: 62-66, 2008.

13. Zhou BO, Yue R, Murphy MM, Peyer JG and Morrison SJ: Leptin-receptor-expressing mesenchymal stromal cells represent the main source of bone formed by adult bone marrow. Cell Stem Cell 15: 154-168, 2014.

14. Hamrick MW, Della-Fera MA, Choi YH, Pennington C, Hartzell D and Baile CA: Leptin treatment induces loss of bone marrow adipocytes and increases bone formation in leptin-deficient ob/ob mice. J Bone Miner Res 20: 994-1001, 2005.

15. Li Y, et al: The study on the leptin level of aplastic anemia. J Clin Hematol 17: 135-136, 2004

16. Guowen Liu, Yuhua Liu, Xiaodan Liu, et al: The expression and significance of leptin and leptin receptor in plasma and bone marrow of AA patients. Acta Academiae Medicinae Qingdao Universitatis 2014: 493-495, 2014.

17. Chen J, Lipovsky K, Ellison FM, Calado RT and Young NS: Bystander destruction of hematopoietic progenitor and stem cells in a mouse model of infusion-induced bone marrow failure. Blood 104: 1671-1678, 2004.

18. Sun J,Wang S, Xie Y and Shi X: Experimental study on animal model of aplastic anemia. Chin J Lab Animal Sci 10: 210-212, 2000.

19. Arieta Kuksin C, Gonzalez-Perez G and Minter LM: CXCR4 expression on pathogenic $\mathrm{T}$ cells facilitates their bone marrow infiltration in a mouse model of aplastic anemia. Blood 125 2087-2094, 2015.

20. Gault N, Verbiest T, Badie C, Romeo PH and Bouffler S: Hematopoietic stem and progenitor cell responses to low radiation doses-implications for leukemia risk. Int J Radiat Biol 17: $1-8,2019$ (Epub ahead of print).

21. Knospe WH, Husseini SG, Chiu KM and Fried W: Immunologically mediated aplastic anemia in mice: Evidence of hematopoietic stromal injury and injury to hematopoietic stem cells. Exp Hematol 22: 573-581, 1994.

22. Sun Z, Yu X, Wang H, Zhang S, Zhao Z and Xu R: Clinical significance of mismatch repair gene expression in sporadic colorectal cancer. Exp Ther Med 8: 1416-1422, 2014.

23. BurrLD, Rogers GB, Chen AC Taylor SL, Bowler SD, Keating RL, Martin ML, Hasnain SZ and McGuckin MA: PPAR $\gamma$ is reduced in the airways of non-CF bronchiectasis subjects and is inversely correlated with the presence of Pseudomonas aeruginosa. PLoS One 13: e0202296, 2018.

24. Li JP, Zheng CL and Han ZC: Abnormal immunity and stem/progenitor cells in acquired aplastic anemia. Crit Rev Oncol Hematol 75: 79-93, 2010.

25. Lin FC, Karwan M, Saleh B, Hodge DL, Chan T, Boelte KC, Keller JR and Young HA: IFN- $\gamma$ causes aplastic anemia by altering hematopoiesis stem/progenitor cell composition and disrupting lineage differentiation. Blood 124: 3699-3708, 2014.
26. Edinger M, Hoffmann P, Ermann J, Drago K, Fathman CG, Strober S and Negrin RS: CD4+ CD25+ regulatory $T$ cells preserve graft-versus-tumor activity while inhibiting graft-versus-host disease after bone marrow transplantation. Nat Med 9: 1144-1150, 2003.

27. Bäckesjö CM, Li Y, Lindgren U and Haldosén LA: Activation of Sirtl decreases adipocyte formation during osteoblast differentiation of mesenchymal stem cells. J Bone Miner Res 21: 993-1002, 2006.

28. Nuttall ME and Gimble JM: Controlling the balance between osteoblastogenesis and adipogenesis and the consequent therapeutic implications. Curr Opin Pharmacol 4: 290-294, 2004.

29. Kawai M and Rosen CJ: PPAR $\gamma$ : A circadian transcription factor in adipogenesis and osteogenesis. Nat Rev Endocrinol 6: 629-236, 2010

30. Fantuzzi G and Faggioni R: Leptin in the regulation of immunity, inflammation, and hematopoiesis. J Leukoc Biol 68: 437-446, 2000.

31. Abella V, Scotece M, Conde J, Pino J, Gonzalez-Gay MA, Gómez-Reino JJ, Mera A, Lago F, Gómez R and Gualillo O: Leptin in the interplay of inflammation, metabolism and immune system disorders. Nat Rev Rheumatol 13: 100-109, 2017.

32. Fernández-Riejos P, Najib S, Santos-Alvarez J, Martín-Romero C, Pérez-Pérez A, González-Yanes C and Sánchez-Margalet V: Role of leptin in the activation of immune cells. Mediators Inflamm 2010: 568343, 2010.

33. Du HZ, Wang Q, Ji J, Shen BM, Wei SC, Liu LJ, Ding J, Ma DX, Wang W, Peng J and Hou M: Expression of IL-27, Th1 and Th17 in patients with aplastic anemia. J Clin Immunol 33: 436-445, 2013.

34. Çakır B, Cevik H, Contuk G, Ercan F, Ekşioğlu-Demiralp E and Yeğen BC: Leptin ameliorates burn-induced multiple organ damage and modulates postburn immune response in rats. Regul Pept 125: 135-144, 2005.

35. Batra A, Okur B, Glauben R, Erben U, Ihbe J, Stroh T, Fedke I, Chang HD, Zeitz $M$ and Siegmund B: Leptin: A critical regulator of $\mathrm{CD} 4+\mathrm{T}$-cell polarization in vitro and in vivo. Endocrinology 151: 56-62, 2010.

36. Han G, Jing Y, Zhang Y, Yue Z, Hu X, Wang L, Liang J and Liu J: Osteogenic differentiation of bone marrow mesenchymal stem cells by adenovirus-mediated expression of leptin. Regul Pept 163: 107-112, 2010

37. Tang QQ, Zhang JW and Lane MD: Sequential gene promoter interactions by $\mathrm{C} / \mathrm{EBPbeta}$, C/EBPalpha, and PPARgamma during adipogenesis. Biochem Biophys Res Commun 318: 213-218, 2004.

38. Komori T: Regulation of bone development and extracellular matrix protein genes by RUNX2. Cell Tissue Res 339: 189-195, 2010.

This work is licensed under a Creative Commons Attribution-NonCommercial-NoDerivatives 4.0 International (CC BY-NC-ND 4.0) License. 